Prepared in cooperation with Colorado Department of Transportation

\title{
Probability and Volume of Potential Postwildfire Debris Flows in the 2012 High Park Burn Area near Fort Collins, Colorado
}

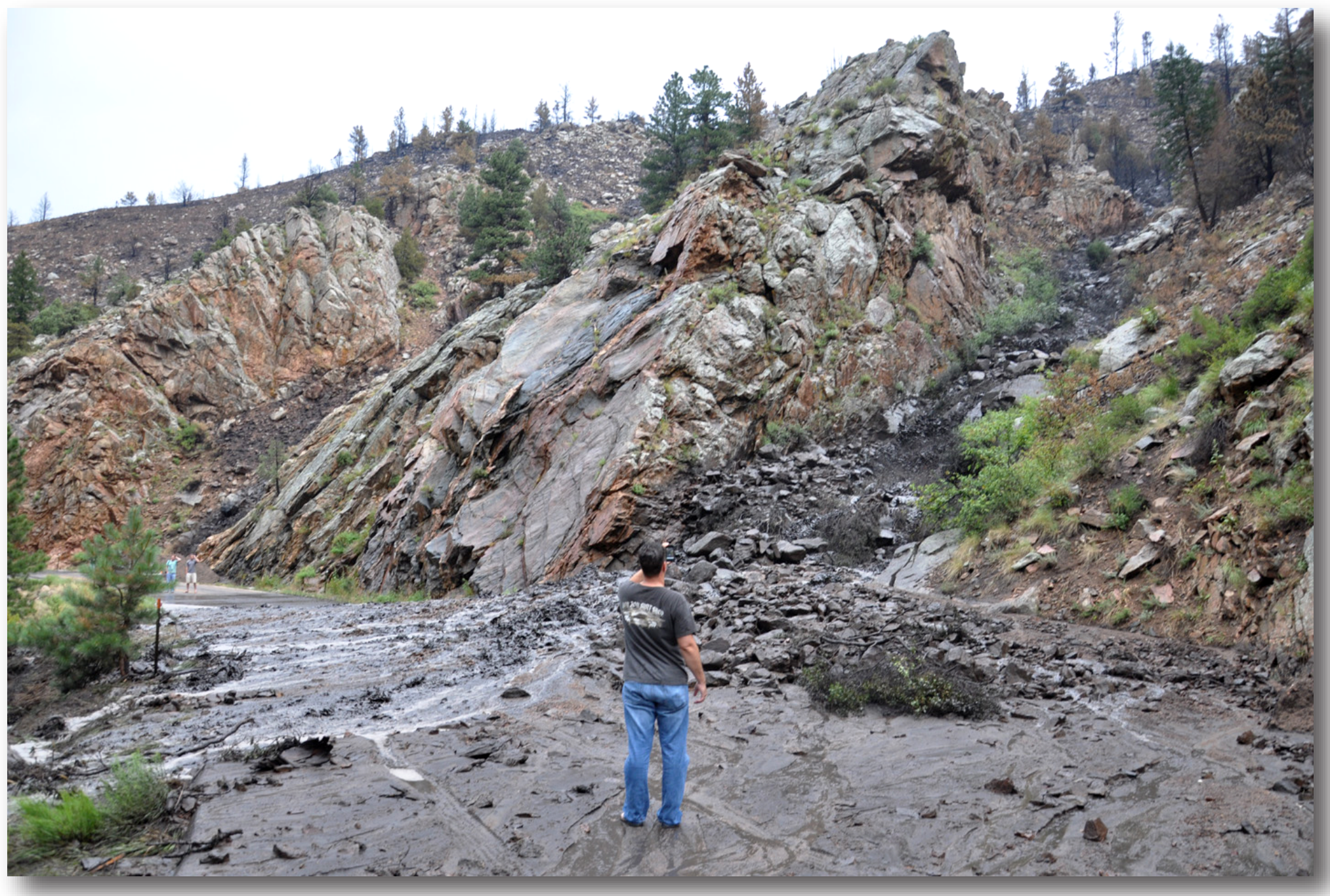

Open-File Report 2012-1148

U.S. Department of the Interior

U.S. Geological Survey 
Cover: Colorado Department of Transportation. The cover photograph was taken on July 7, 2012, in Poudre Canyon. The road shown is Colorado State Highway 14. 


\section{Probability and Volume of Potential Postwildfire Debris Flows in the 2012 High Park Burn Area near Fort Collins, Colorado}

By Kristine L. Verdin, Jean A. Dupree, and John G. Elliott

Prepared in cooperation with Colorado Department of Transportation

Open-File Report 2012-1148

U.S. Department of the Interior

U.S. Geological Survey 


\section{U.S. Department of the Interior \\ KEN SALAZAR, Secretary}

\section{U.S. Geological Survey Marcia K. McNutt, Director}

U.S. Geological Survey, Reston, Virginia: 2012

For product and ordering information:

World Wide Web: http://www.usgs.gov/pubprod

Telephone: 1-888-ASK-USGS

For more information on the USGS-the Federal source for science about the Earth, its natural and living resources, natural hazards, and the environment:

World Wide Web: http://www.usgs.gov

Telephone: 1-888-ASK-USGS

\section{Suggested citation:}

Verdin, K.L., Dupree, J.A., and Elliott, J.G., 2012, Probability and volume of potential postwildfire debris flows in the 2012 High Park Burn Area near Fort Collins, Colorado: U.S. Geological Survey Open-File Report 2012-1148, 9 p.

Any use of trade, product, or firm names is for descriptive purposes only and does not imply endorsement by the U.S. Government.

Although this report is in the public domain, permission must be secured from the individual copyright owners to reproduce any copyrighted material contained within this report. 


\section{Contents}

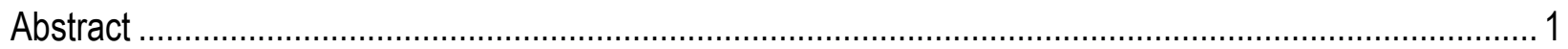

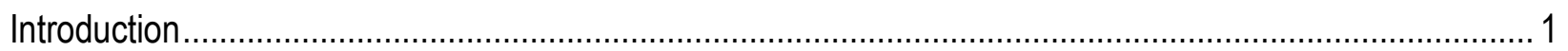

Probability and Volume of Potential Debris Flows ............................................................................... 4

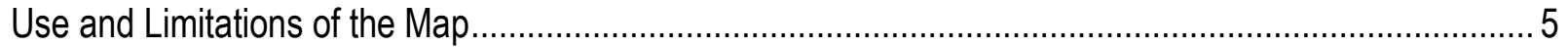

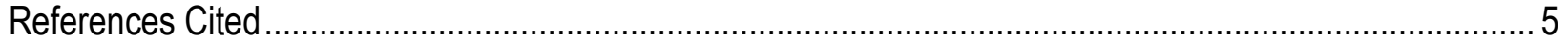

\section{Figure}

1. Location and severity of the 2012 High Park fire near Fort Collins, Colo .......................................... 7

\section{Plates}

1. Estimated probability of potential postwildfire debris flows in the 2012 High Park Burn Area near Fort Collins, Colo. link

2. Estimated volumes of potential postwildfire debris flows in the 2012 High Park Burn Area near Fort Collins, Colo link

\section{Table}

1. Estimated debris-flow probabilities and volumes for the 2012 High Park fire near

Fort Collins, Colo. 8 


\section{Conversion Factors}

SI to Inch/Pound

\begin{tabular}{lll}
\hline \multicolumn{1}{c}{ Multiply } & By & \multicolumn{1}{c}{ To obtain } \\
\hline millimeter $(\mathrm{mm})$ & Length & \\
meter $(\mathrm{m})$ & 0.03937 & inch (in.) \\
meter $(\mathrm{m})$ & 3.281 & foot $(\mathrm{ft})$ \\
\hline kilometer $(\mathrm{km})$ & 1.094 & yard $(\mathrm{yd})$ \\
\hline & 0.6214 & mile $(\mathrm{mi})$ \\
\hline square meter $\left(\mathrm{m}^{2}\right)$ & Area & \\
square kilometer $\left(\mathrm{km}^{2}\right)$ & 0.0002471 & acre \\
\hline & 0.3861 & square mile $\left(\mathrm{mi}^{2}\right)$ \\
\hline cubic meter $\left(\mathrm{m}^{3}\right)$ & Volume & \\
cubic meter $\left(\mathrm{m}^{3}\right)$ & 35.31 & cubic foot $\left(\mathrm{ft}^{3}\right)$ \\
cubic meter $\left(\mathrm{m}^{3}\right)$ & 1.308 & cubic yard $\left(\mathrm{yd}^{3}\right)$ \\
& 0.0008107 & acre-foot $(\mathrm{acre}-\mathrm{ft})$ \\
\hline millimeter per year $(\mathrm{mm} / \mathrm{yr})$ & Flow rate & \\
\hline
\end{tabular}

Vertical coordinate information is referenced to the North American Vertical Datum of 1988 (NAVD 88).

Horizontal coordinate information is referenced to the North American Datum of 1983 (NAD 83). 


\title{
Probability and Volume of Potential Postwildfire Debris Flows in the 2012 High Park Burn Area near Fort Collins, Colorado
}

\author{
By Kristine L. Verdin, Jean A. Dupree, and John G. Elliott
}

\begin{abstract}
This report presents a preliminary emergency assessment of the debris-flow hazards from drainage basins burned by the 2012 High Park fire near Fort Collins in Larimer County, Colorado. Empirical models derived from statistical evaluation of data collected from recently burned basins throughout the intermountain western United States were used to estimate the probability of debris-flow occurrence and volume of debris flows along the burned area drainage network and to estimate the same for 44 selected drainage basins along State Highway 14 and the perimeter of the burned area. Input data for the models included topographic parameters, soil characteristics, burn severity, and rainfall totals and intensities for a (1) 2-year-recurrence, 1-hour-duration rainfall (25 millimeters); (2) 10-year-recurrence, 1-hour-duration rainfall (43 millimeters); and (3) 25-year-recurrence, 1-hour-duration rainfall (51 millimeters).

Estimated debris-flow probabilities along the drainage network and throughout the drainage basins of interest ranged from 1 to 84 percent in response to the 2 -year-recurrence, 1-hour-duration rainfall; from 2 to 95 percent in response to the 10 -year-recurrence, 1-hourduration rainfall; and from 3 to 97 in response to the 25-year-recurrence, 1-hour-duration rainfall. Basins and drainage networks with the highest probabilities tended to be those on the eastern edge of the burn area where soils have relatively high clay contents and gradients are steep. Estimated debris-flow volumes range from a low of 1,600 cubic meters to a high of greater than 100,000 cubic meters. Estimated debris-flow volumes increase with basin size and distance along the drainage network, but some smaller drainages were also predicted to produce substantial volumes of material. The predicted probabilities and some of the volumes predicted for the modeled storms indicate a potential for substantial debris-flow impacts on structures, roads, bridges, and culverts located both within and immediately downstream from the burned area. Colorado State Highway 14 is also susceptible to impacts from debris flows.
\end{abstract}

\section{Introduction}

The objective of this report is to present a preliminary emergency assessment of the debris-flow hazards from basins burned by the 2012 High Park fire near Fort Collins in Larimer County, Colorado. Debris flows have been documented after many fires in the western United States (Cannon and others, 2010), and can threaten lives, property, infrastructure, aquatic habitats, and water supplies. Wildfires can denude hillslopes of vegetation and change soil properties that affect watershed hydrology and sediment-transport processes. Even small postwildfire rainstorms can increase overland runoff that erodes soil, rock, ash, and vegetative 
debris from hillslopes (Cannon and others, 2008). This increased runoff concentrates in stream channels and entrains the sediment that can lead to the generation of destructive debris flows. Debris flow hazards are most significant up to 3 years (yr) following wildfires (Susan Cannon, U.S. Geological Survey, written commun., 2010). Field inspection within the area burned by the High Park fire identified debris-flow deposits in several locations, indicating that the area is susceptible to debris flows. It is unknown, however, if these debris flows occurred postwildfire.

This report, done in cooperation with the Colorado Department of Transportation, presents an assessment of the debris-flow hazards from drainage basins burned in 2012 by the High Park wildfire west of Fort Collins, Colorado (Colo.). The High Park wildfire burned more than 65,000 acres within a burn perimeter of more than 90,000 acres (fig. 1). This report provides estimates of the predicted probability of debris-flow occurrence and volume of debris along the drainage network throughout the entire area, as well as estimates for drainage basins above 44 selected basin outlets in response to three design storms: (1) 2-year-recurrence, 1-hour duration rainfall of 25 millimeters (mm) (a 50-percent chance of occurrence in any given year); (2) 10year-recurrence, 1-hour-duration rainfall of $43 \mathrm{~mm}$ (a 10-percent chance of occurrence in any given year); and (3) 25-year-recurrence, 1-hour-duration rainfall of $51 \mathrm{~mm}$ (a 4-percent chance of occurrence in any given year). These design events were defined from data and methods detailed in the National Oceanic and Atmospheric Administration's (NOAA) PrecipitationFrequency Atlas of the Western United States (Miller and others, 1973).

A set of empirical equations (models) documented in Cannon and others (2010) and derived from statistical evaluation of data collected from recently burned basins throughout the intermountain western United States were used to estimate the probability of debris-flow occurrence and volumes of debris flows along the drainage network and for selected drainage basins. The regression equation of debris-flow probability (eq. 1) is as follows:

where

$$
P=e^{x} /\left(1+e^{x}\right)
$$

$P$ is the probability of debris-flow occurrence in fractional form; and

where

$x=-0.7+0.03(\% S G 30)-1.6(R)+0.06(\% A B)+0.07(I)+0.2(\% C)-0.4(L L)$,

$\% S G 30$ is the percentage of the drainage-basin area with slope equal to or greater than 30 percent;

$R$ is drainage-basin ruggedness: the change in drainage-basin elevation (meters) divided by the square root of the drainage-basin area (square meters) (Melton, 1965);

$\% A B$ is the percentage of drainage-basin area burned at moderate to high severity (data for this investigation from Amy Coe, U.S. Department of Agriculture Forest Service, written commun., 2012);

$I$ is average storm intensity (calculated by dividing total storm rainfall [Miller and others, 1973] by the storm duration, in millimeters per hour);

$\% C$ is clay content of the soil (in percent) (National Soil Survey Center, 1991); and

$L L$ is the liquid limit of the soil (percentage of soil moisture by weight) (National Soil Survey Center, 1991).

Cannon and others (2010) also developed an empirical model that can be used to estimate the volume of debris flow that would likely be produced from recently burned drainage basins: 


$$
\operatorname{Ln} V=7.2+0.6(\ln S G 30)+0.7(A B)^{0.5}+0.2(T)^{0.5}+0.3
$$

where

$V$ is the debris-flow volume, including water, sediment, and debris (cubic meters); $S G 30$ is the area of drainage basin with slopes equal to or greater than 30 percent (square kilometers);

$A B$ is the drainage basin area burned at moderate to high severity (square kilometers); $T$ is the total storm rainfall (millimeters); and

0.3 is a bias-correction factor that changes the predicted estimate from a median to a mean value (Helsel and Hirsch, 2002).

Values for both probability and volume were obtained along drainage networks using the continuous parameterization technique (Verdin and Greenlee, 2003; Verdin and Worstell, 2008). With this technique, estimates of debris-flow probability and volume (Cannon and others, 2010) were obtained for every 10-meter (m) pixel along the drainage network (plates 1 and 2 ) as a function of conditions in the drainage basin above each pixel. This technique was developed as an alternative to basin-characterization approaches used in the past (for example, Cannon and others, 2009), which require definition of outlets (pour points) at the beginning of the analysis, and their corresponding basins. The technique used here allows for a synoptic view of conditions throughout the entire study area, which can be used to identify specific $10-\mathrm{m}$ cells or stream reaches that might be in danger; the technique also aids in sampling design and monitoring-site selection.

The base layer upon which the continuous-parameterization layers are built is the 1/3-arcsecond National Elevation Dataset (Gesch and others, 2002). This digital elevation model (DEM) was projected into a Colorado-appropriate projection system (UTM, Zone 13) and processed using standard DEM-conditioning tools in ArcGIS (ESRI, 2009) and RiverTools (Rivix, 2012). Once the overland flow structure was derived (in the form of a flow-direction matrix) using the DEM, the independent variables driving the probability and volume equations were evaluated for every grid cell within the extent of the DEM. Input rainfall totals and rainfall intensities will vary over the extent of the burn; the highest rainfall amounts will be located near the eastern base of the foothills, and higher amounts will be located farther up the Poudre Canyon and higher in elevation (Nolan Doesken, Colorado State Climatologist, written commun., 2012). For this study, however, the maximum rainfall amounts for each storm were assumed to be uniform over the entire burn area, providing the most conservative estimate of the probability and volumes of potential debris flows. Values for all of the other independent variables driving the debris-flow and volume equations were obtained using the continuous-parameterization approach. Once the surfaces of the independent variables were developed, the probability and volume equations were solved using map algebra for each grid cell along the drainage network. Identification of the probability or volume of a debris flow at locations within the study area can be obtained by querying the derived surfaces.

Following calculation of debris-flow probabilities and volumes continuously along the drainage networks, 44 basins of interest along State Highway 14 and the burn perimeter were identified. Debris-flow probabilities and volumes were extracted from the probability and volume surface for these locations. These values are shown in plates 1 and 2 and summarized in table 1 . 


\section{Probability and Volume of Potential Debris Flows}

In response to the 2-year-recurrence, 1-hour-duration rainfall, three basins affected by the burn (basins 19, 20 and 21; table 1) were identified as having probabilities of debris-flow occurrence greater than 60 percent, and 2 basins ( 4 and 22) had probabilities between 40 and 60 percent. These are all relatively small basins with drainage areas ranging from 0.5 to 4.6 square kilometers $\left(\mathrm{km}^{2}\right)$. Estimated volumes of debris flows for these five basins ranged from 4,500 to 29,000 cubic meters $\left(\mathrm{m}^{3}\right)$. In addition, volumes greater than about $100,000 \mathrm{~m}^{3}$ were calculated for 9 basins. These values indicate a substantial risk of debris flow in response to a storm with a 50 -percent chance of impacting the area each year.

The 10-year-recurrence, 1-hour-duration rainfall resulted in more basins with a higher probability of debris flow (plate 1, table 1). Seven basins (4, 18, 19, 20, 21, 22, and 27) had probabilities of debris flow in excess of 60 percent with corresponding volume estimates from $6,200 \mathrm{~m}^{3}$ to $39,000 \mathrm{~m}^{3}$. These basins are located on the northern and eastern edge of the burned area and range in size from 0.5 to $4.6 \mathrm{~km}^{2}$. The volume estimates displayed in plate 2 indicates 11 basins with potential yields in excess of $100,000 \mathrm{~m}^{3}$ in response to the 10 -year-recurrence/1hour-duration rainfall event. The high volumes are produced by larger streams that drain the entirety of the burn area as well as being produced by large streams entering the burn areas from the east and north (South Fork Cache la Poudre River [43] and Hewlett Gulch [28]). While the volume equation predicts large volumes for these basins, the probability of a debris flow for several of the larger basins (South Fork Cache la Poudre River [43], Hewlett Gulch [28], and Bennett Creek [44]) is very low (only 3 to 6 percent) in response to the 10 -year-recurrence, 1hour-duration storm. However, several of the basins with volume estimates in excess of 100,000 $\mathrm{m}^{3}$ also have corresponding probabilities in excess of 40 percent (Lewstone Creek [16], Poverty Gulch [42], Skin Gulch [40], Rist Canyon [3] and Watha Gulch [26]). The volumes and probabilities calculated for these basins indicate a substantial risk of debris flow in response to a storm with a 10 -percent chance of occurring each year.

The additional detail provided by the continuous-parameterization technique can be seen in plate 1. For example, the estimated probabilities at the pour points for Redstone Creek (9) and Stove Prairie Creek (11) are 19 percent and 28 percent, respectively. Examination of the drainage network upstream of these two pour points reveals many drainage channels with estimated probabilities above 60 percent. The 25-year-recurrence,1-hour-duration storm shows additional basins with higher probabilities of debris flows (table 1), and significantly higher volumes are produced in response to this storm as well. Twelve basins show a probability of debris flow in excess of 60 percent and an additional seven basins have a probability between 40 and 59 percent. Only 13 basins are modeled as expected to produce debris-flow volumes less than about $10,000 \mathrm{~m}^{3}$. These 13 basins are located on the periphery of the burn and all have drainage areas less than $1 \mathrm{~km}^{2}$. Probabilities and volumes calculated in response to the 25 -yearrecurrence storm indicate that should this storm occur (there is a 4-percent chance each year), destructive debris flows can be expected from many of the drainage basins burned by the High Park fire. The predicted probabilities and volumes in response to the three storm varieties indicate a potential for substantial debris-flow effects to buildings, roads, bridges, culverts, and reservoirs located both within drainages and immediately downstream from the burned area. In addition, even small debris flows that affect structures at the basin outlets could cause considerable damage. 


\section{Use and Limitations of the Map}

This assessment provides estimates of debris-flow probability and volume for drainage basins burned by the High Park fire in response to three design storms based on predictive models developed from data from burned areas throughout the western United States. The predictive models were not developed from data from basins burned by this fire. Larger, less-frequent storms are more likely to produce much larger debris flows. Because individual storms may not affect the entire area at any given time, debris flows may not be produced from all basins during storms. The estimates are meant to be valid for up to $3 \mathrm{yr}$ after the fire (Susan Cannon, U.S. Geological Survey, written commun., 2010).

The plates may be used to prioritize areas where emergency-flood warnings or erosion mitigation may be needed prior to rainstorms within these basins, their outlets, or areas downstream from these basins. This assessment evaluates only postwildfire debris flows (Cannon and others, 2007). Substantial hazards from flash floods without debris flow may remain for many years after a fire.

This work is preliminary and is subject to revision. It is being provided owing to the need for timely "best science" information. The assessment is provided on the condition that neither the U.S. Geological Survey nor the United States Government may be held liable for any damages resulting from the authorized or unauthorized use of the assessment.

\section{References Cited}

Cannon, S.H., Gartner, J.E., and Michael, J.A., 2007, Methods for the emergency assessment of debris-flow hazards from basins burned by the fires of 2007, southern California: U.S. Geological Survey Open-File Report 2007-1384, 10 p. (Also available at http://pubs.usgs.gov/of/2007/1384/.)

Cannon, S.H., Gartner, J.E., Rupert, M.G., Michael, J.A., Staley, D.B., and Worstell, B.B., 2009, Emergency assessment of postfire debris-flow hazards for the 2009 Station Fire, San Gabriel Mountains, Southern California: U.S. Geological Survey Open-File Report 2009-1227, 27 p. (Also available at $h$ ttp://pubs.usgs.gov/of/2009/1227/.)

Cannon, S.H., Gartner, J.E., Wilson, R.C., and Laber, J.L., 2008, Storm rainfall conditions for floods and debris flows from recently burned areas in southwestern Colorado and southern California: Geomorphology, v. 96, p. 250-269, doi:10.1019/j.geomorph.2008.03.019.

Cannon, S.H., Gartner, J.E., Rupert, M.G., Michael, J.A., Rea, A.H., and Parrett, C., 2010, Predicting the probability and volume of postwildfire debris flows in the intermountain western United States: Geological Society of America Bulletin, v. 122, p. 127-144.

ESRI, 2009, ArcGIS v. 9.3: Redlands, Calif., ESRI.

Gesch, D., Oimoen, M., Greenlee, S., Nelson, C., Steuck, M., and Tyler, D., 2002, The national elevation dataset: Photogrammetric Engineering and Remote Sensing, v. 68, no. 1, p. 5-11.

Helsel, D.R., and Hirsch, R.M., 2002, Statistical methods in water resources: New York, N.Y., Elsevier Studies in Environmental Science, v. 49, 529 p.

Melton, M.A., 1965, The geomorphic and paleoclimate significance of alluvial deposits in southern Arizona: Journal of Geology, v. 73, p. 1-38.

Miller, J.F., Frederick, R.H., and Tracey, R.J., 1973, Precipitation-frequency atlas of the western United States, v. 3-Colorado: Silver Spring, Md., U.S. Department of Commerce, National Oceanic and Atmospheric Administration Atlas 2, National Weather Service. 
Rivix, LLC, 2012, RiverTools 3.0.3: Broomfield, Colo., Rivix, LLC, accessed July, 2012, at http://rivix.com.

National Soil Survey Center, 1991, State Soil Geographic (STATSGO) database—Data use information: U.S. Department of Agriculture, National Resources Conservation Service, Miscellaneous Publication 1492, 110 p. [Revised July, 1994]

Verdin, K.L. and Greenlee, S., 2003, Continuous parameterization using EDNA, in 2003 ESRI User's Conference, San Diego, Calif., July 7-11, 2003, Proceedings: Redlands, Calif., ESRI, accessed June, 2012, at http://gis.esri.com/library/userconf/proc03/p0617.pdf.

Verdin, K. L., and Worstell, B., 2008, A fully distributed implementation of mean annual streamflow regional regression equations: Journal of the American Water Resources Association, v. 44, p. 1537-1547, doi: 10.1111/j.1752-1688.2008.00258.x 


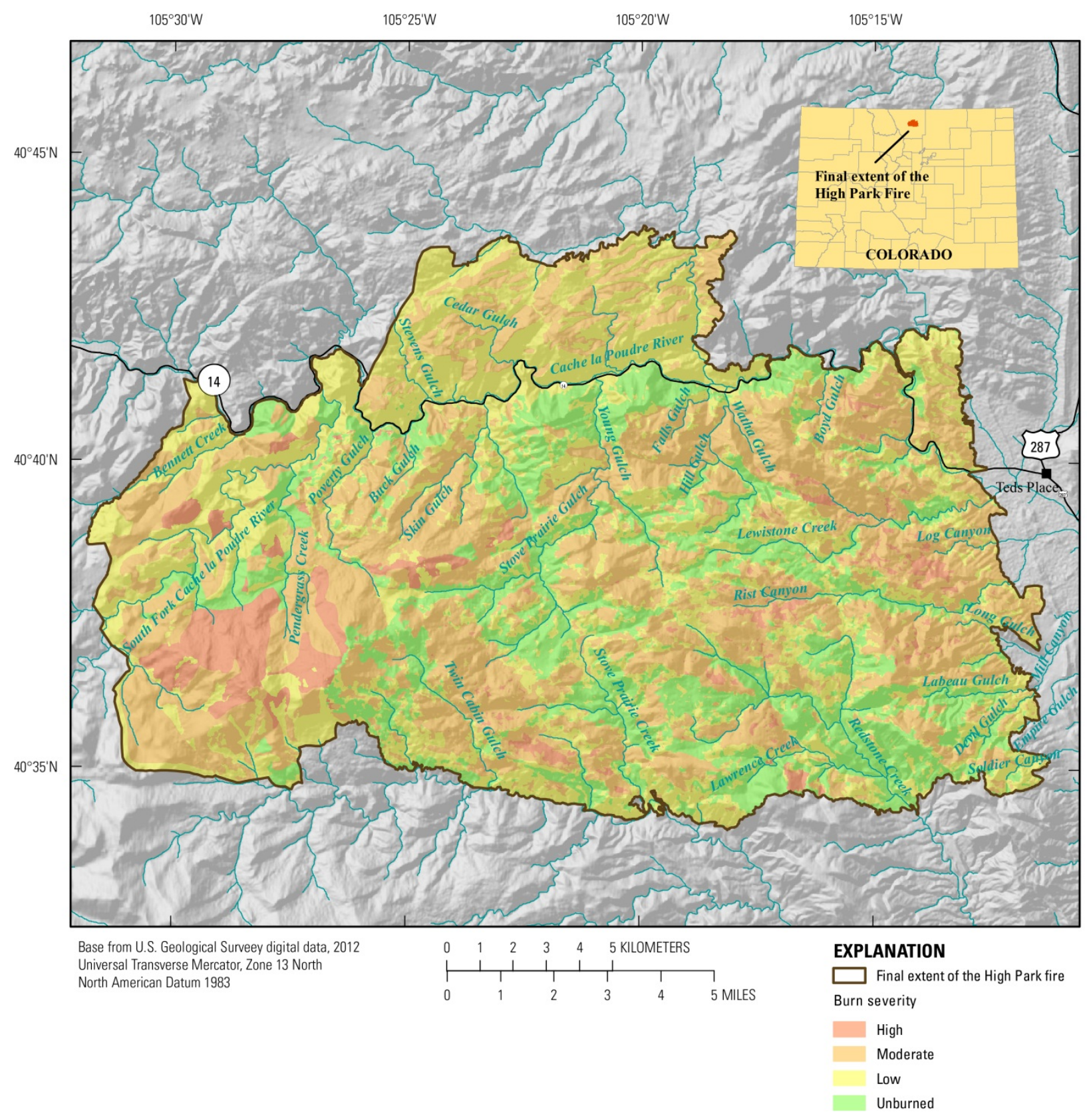

Figure 1. Location and severity of the 2012 High Park fire near Fort Collins, Colo. 
Table 1. Estimated debris-flow probabilities and volumes for the 2012 High Park fire near Fort Collins, Colo. (mm, millimeters; $\mathrm{km}^{2}$, square kilometers; \%, percent; $\mathrm{m}^{3}$, cubic meters; >, greater than)

\begin{tabular}{|c|c|c|c|c|c|c|c|c|c|c|}
\hline \multirow[b]{3}{*}{ Basin } & \multirow[b]{3}{*}{ Description } & \multirow{2}{*}{\multicolumn{2}{|c|}{ Basin Pour Point }} & \multirow{3}{*}{$\begin{array}{c}\text { Drainage } \\
\begin{array}{c}\text { Area } \\
\mathrm{km}^{2}\end{array}\end{array}$} & \multicolumn{2}{|c|}{ 2-year/1-hour precipitation } & \multicolumn{2}{|c|}{ 10-year/1-hour precipitation } & \multicolumn{2}{|c|}{ 25-year/1-hour precipitation } \\
\hline & & & & & & $4 \mathrm{~mm}$ & & $\mathrm{~mm}$ & & $8 \mathrm{~mm}$ \\
\hline & & Latitude & Longitude & & $\begin{array}{c}\text { Probability } \\
(\%)\end{array}$ & $\begin{array}{c}\text { Volume } \\
\left(\mathrm{m}^{3}\right)\end{array}$ & $\begin{array}{c}\text { Probability } \\
(\%)\end{array}$ & $\begin{array}{c}\text { Volume } \\
\left(\mathrm{m}^{3}\right)\end{array}$ & $\begin{array}{c}\text { Probability } \\
(\%)\end{array}$ & $\begin{array}{c}\text { Volume } \\
\left(\mathrm{m}^{3}\right)\end{array}$ \\
\hline 1 & Buck Gulch & 40.6739 & -105.4173 & 2.0 & 7 & 9,600 & 20 & 13,000 & 30 & 15,000 \\
\hline 2 & Unnamed Creek near Hwy 14. mile marker 97 & 40.6794 & -105.4826 & 2.1 & 6 & 9,700 & 19 & 13,000 & 28 & 15,000 \\
\hline 3 & Rist Canyon & 40.6457 & -105.1951 & 16.5 & 26 & $>100,000$ & 55 & $>100,000$ & 67 & $>100,000$ \\
\hline 4 & Log Canyon & 40.6458 & -105.1952 & 4.6 & 50 & 29,000 & 78 & 39,000 & 86 & 44,000 \\
\hline 5 & Mill Canyon & 40.6175 & -105.1838 & 9.2 & 9 & 44,000 & 25 & 60,000 & 37 & 67,000 \\
\hline 6 & Long Gulch & 40.6176 & -105.1839 & 6.8 & 25 & 44,000 & 53 & 60,000 & 66 & 67,000 \\
\hline 7 & Empire Gulch & 40.6106 & -105.1738 & 2.3 & 1 & 7,400 & 4 & 10,000 & 7 & 11,000 \\
\hline 8 & Soldier Canyon & 40.5885 & -105.1773 & 2.2 & 3 & 8,100 & 8 & 11,000 & 13 & 12,000 \\
\hline 9 & Redstone Creek & 40.5728 & -105.2360 & 38.8 & 6 & $>100,000$ & 19 & $>100,000$ & 29 & $>100,000$ \\
\hline 10 & Unnamed Creek flowing to Buckhorn Creek near Deadman Hill & 40.5666 & -105.3128 & 1.6 & 5 & 7,200 & 15 & 9,800 & 23 & 11,000 \\
\hline 11 & Stove Prairie Creek flowing to Buckhorn Creek & 40.5711 & -105.3300 & 16.8 & 10 & $>100,000$ & 28 & $>100,000$ & 40 & $>100,000$ \\
\hline 12 & Unnamed creek (Paradise Park) flowing to Buckhorn Creek & 40.5719 & -105.3512 & 4.3 & 17 & 18,000 & 42 & 24,000 & 55 & 27,000 \\
\hline 13 & Twin Cabin Gulch & 40.5774 & -105.3868 & 9.8 & 19 & 71,000 & 46 & 96,000 & 59 & $>100,000$ \\
\hline 14 & Unnamed creek (East White Pine Mountain) flowing to Buckhorn Creek & 40.5835 & -105.4123 & 3.8 & 3 & 17,000 & 10 & 23,000 & 16 & 26,000 \\
\hline 15 & Unnamed creek near near Hwy 14. at mile marker 121 (west of Ted's Place) & 40.6653 & -105.2023 & 5.6 & 4 & 19,000 & 12 & 26,000 & 18 & 29,000 \\
\hline 16 & Lewstone Creek & 40.6592 & -105.2047 & 17.7 & 19 & $>100,000$ & 44 & $>100,000$ & 58 & $>100,000$ \\
\hline 17 & Unnamed Creek near Hwy 14. west of mile marker 119 & 40.6709 & -105.2367 & 1.7 & 26 & 11,000 & 55 & 14,000 & 67 & 16,000 \\
\hline 18 & Unnamed Creek near Hwy 14. northwest of mile marker 119 & 40.6727 & -105.2389 & 3.0 & 39 & 19,000 & 69 & 25,000 & 79 & 28,000 \\
\hline 19 & Unnamed Creek near Hwy 14. northwest of mile marker 118 & 40.6844 & -105.2379 & 0.7 & 84 & 6,300 & 95 & 8,600 & 97 & 9,600 \\
\hline 20 & Unnamed Creek near Hwy 14. northwest of mile marker 118 & 40.6851 & -105.2395 & 0.5 & 77 & 4,500 & 92 & 6,200 & 95 & 6,900 \\
\hline 21 & Unnamed Creek near Hwy 14. between mile markers 115 and 116 & 40.6918 & -105.2559 & 0.7 & 65 & 5,900 & 86 & 8,100 & 92 & 9,000 \\
\hline 22 & Boyd Gulch & 40.6928 & -105.2646 & 3.2 & 47 & 23,000 & 75 & 32,000 & 84 & 36,000 \\
\hline 23 & Unnamed Creek near Hwy 14. between mile markers 113 and 114 & 40.6953 & -105.2822 & 0.2 & 2 & 1,600 & 6 & 2,200 & 9 & 2,500 \\
\hline 24 & Unnamed creek draining Greyrock Meadow & 40.6950 & -105.2872 & 3.3 & 3 & 9,300 & 10 & 13,000 & 16 & 14,000 \\
\hline 25 & Unnamed creek near Hwy 14. south of mile marker 113 & 40.6903 & -105.2873 & 0.6 & 3 & 4,000 & 11 & 5,500 & 17 & 6,200 \\
\hline
\end{tabular}


Table 1. Estimated debris-flow probabilities and volumes for the 2012 High Park fire near Fort Collins, Colo. - Continued ( $\mathrm{mm}$, millimeters; $\mathrm{km}^{2}$, square kilometers; \%, percent; $\mathrm{m}^{3}$, cubic meters; >, greater than)

\begin{tabular}{|c|c|c|c|c|c|c|c|c|c|c|}
\hline \multirow[b]{3}{*}{ Basin } & \multirow[b]{3}{*}{ Description } & \multirow{2}{*}{\multicolumn{2}{|c|}{ Basin Pour Point }} & \multirow{3}{*}{$\begin{array}{c}\text { Drainage } \\
\text { Area } \\
\mathrm{km}^{2}\end{array}$} & \multicolumn{2}{|c|}{ 2-year/1-hour precipitation } & \multicolumn{2}{|c|}{ 10-year/1-hour precipitation } & \multicolumn{2}{|c|}{ 25-year/1-hour precipitation } \\
\hline & & & & & & $4 \mathrm{~mm}$ & & mm & & $8 \mathrm{~mm}$ \\
\hline & & Latitude & Longitude & & $\begin{array}{c}\text { Probability } \\
(\%)\end{array}$ & $\begin{array}{c}\text { Volume } \\
\left(\mathrm{m}^{3}\right)\end{array}$ & $\begin{array}{c}\text { Probability } \\
\text { (\%) }\end{array}$ & $\begin{array}{c}\text { Volume } \\
\left(\mathrm{m}^{3}\right)\end{array}$ & $\begin{array}{c}\text { Probability } \\
(\%)\end{array}$ & $\begin{array}{c}\text { Volume } \\
\left(\mathrm{m}^{3}\right)\end{array}$ \\
\hline 26 & Watha Gulch/Hill Gulch & 40.6872 & -105.3027 & 14.4 & 28 & $>100,000$ & 57 & $>100,000$ & 69 & $>100,000$ \\
\hline 27 & Falls Gulch & 40.6877 & -105.3089 & 3.5 & 32 & 24,000 & 62 & 32,000 & 74 & 36,000 \\
\hline 28 & Hewlett Gulch & 40.6881 & -105.3074 & 56.4 & 2 & $>100,000$ & 6 & $>100,000$ & 10 & $>100,000$ \\
\hline 29 & Unnamed creek west of mile marker 111 & 40.6892 & -105.3222 & 0.4 & 1 & 2,600 & 3 & 3,500 & 5 & 3,900 \\
\hline 30 & Unnamed creek between mile marker 110 and 111 & 40.6930 & -105.3263 & 0.4 & 5 & 3,300 & 15 & 4,500 & 24 & 5,000 \\
\hline 31 & Unnamed creek just east of mile marker 110 & 40.6942 & -105.3282 & 0.4 & 2 & 2,800 & 8 & 3,800 & 13 & 4,300 \\
\hline 32 & Unnamed creek east of mile marker 110 near Diamond Rock Picnic Area & 40.6932 & -105.3329 & 0.6 & 4 & 3,700 & 12 & 5,000 & 19 & 5,600 \\
\hline 33 & Unnamed creek west of mile marker 110 & 40.6942 & -105.3369 & 0.3 & 3 & 2,400 & 8 & 3,200 & 13 & 3,600 \\
\hline 34 & Unnamed creek west of mile marker 110 & 40.6927 & -105.3377 & 0.3 & 1 & 2,600 & 3 & 3,500 & 5 & 3,900 \\
\hline 35 & Unnamed creek between mile markers 109 and 110 & 40.6913 & -105.3401 & 4.5 & 11 & 20,000 & 31 & 27,000 & 43 & 30,000 \\
\hline 36 & Young Gulch & 40.6902 & -105.3495 & 39.7 & 10 & $>100,000$ & 27 & $>100,000$ & 39 & $>100,000$ \\
\hline 37 & Unnamed creek west of mile marker 109 & 40.6881 & -105.3562 & 0.3 & 2 & 2,500 & 6 & 3,400 & 10 & 3,800 \\
\hline 38 & Unnamed creek near mile marker 108 & 40.6872 & -105.3691 & 0.4 & 2 & 2,700 & 6 & 3,700 & 9 & 4,100 \\
\hline 39 & Cedar Gulch & 40.6933 & -105.3786 & 5.2 & 18 & 27,000 & 43 & 36,000 & 57 & 40,000 \\
\hline 40 & Skin Gulch (contains Stove Prairie Road) & 40.6828 & -105.3900 & 15.5 & 24 & $>100,000$ & 53 & $>100,000$ & 65 & $>100,000$ \\
\hline 41 & Stevens Gulch & 40.6840 & -105.4094 & 4.5 & 6 & 17,000 & 17 & 23,000 & 26 & 26,000 \\
\hline 42 & Poverty Gulch & 40.6746 & -105.4290 & 11.2 & 19 & 85,000 & 45 & $>100,000$ & 58 & $>100,000$ \\
\hline 43 & South Fork Cache la Poudre River & 40.6864 & -105.4472 & 268.7 & 1 & $>100,000$ & 4 & $>100,000$ & 6 & $>100,000$ \\
\hline 44 & Bennett Creek & 40.6740 & -105.4782 & 37.2 & 1 & 89,000 & 3 & $>100,000$ & 5 & $>100,000$ \\
\hline
\end{tabular}

